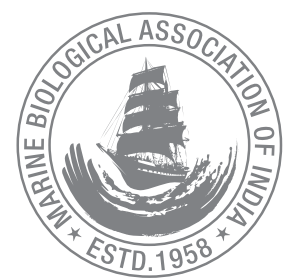

\title{
Spatial variability and abundance pattern of Indian squid off Maharashtra coast, India
}

\author{
Santosh N. Bhendekar", K. Sunil Mohamed', Latha Shenoy², A. P. Dineshbabu ${ }^{3}$, J. Jayasankar', \\ A. K. Jaiswar², V. V. Singh and Anulekshmi Chellappan \\ Mumbai Research Centre of ICAR-Central Marine Fisheries Research Institute, Mumbai. \\ ${ }^{1}$ ICAR-Central Marine Fisheries Research Institute, Kochi. \\ ${ }^{2}$ FRHPHM Division, ICAR-Central Institute of Fisheries Education, Mumbai. \\ ${ }^{3}$ Mangalore Research Centre of ICAR-Central Marine Fisheries Research Institute, Mangalore. \\ *Correspondence e-mail: santucofs@gmail.com
}

Received: 20 Dec 2018 Accepted: 25 Jan 2019 Published: 30 Jan 2019

Original Article

\begin{abstract}
An analysis was carried out on monthly spatial distribution and unusual congregation of Indian squid (Uroteuthis (Photololigo) duvaucelii) off Maharashtra coast. Decadal, annual and monthly squid landing data were taken from National Marine Living Resources Data Centre (NMLRDC) of ICAR-CMFRI. Onboard fisheries information were collected from multi-day trawlers operating from Mumbai and Ratnagiri. Ocean environment parameters coming from Copernicus Marine Service Information with 1/12 degree horizontal resolution and 50 vertical depth level and OSCAR (Ocean Surface Current Analysis Real-time) near-surface ocean current estimates was derived using quasi-linear and steady flow momentum equations on a 1/3 degree grid with a 5 day resolution. In last decade, contribution of squid to total marine fish landing of Maharashtra rose from $2 \%$ to $7.3 \%$. The decadal landing shows two peaks in 2012 and 2017. Indian squid landing in 2017 shows two peak, one during August to October confined to $15^{\circ} \mathrm{N}$ to $17^{\circ} \mathrm{N}$ latitude in 15 to $60 \mathrm{~m}$ depth off south Maharashtra and second in summer, during March-April months widely scattered in north and south Maharashtra. The unusual abundance of Indian squid during mid-October to mid- November 2017 were attributed to rise in coastal surface and subsurface temperature. Catch per hour of trawl and SST shows strong positive correlation (0.79) during the same period.
\end{abstract}

Keywords: Indian squid, spatial distribution, trawl fishery, abundance, SST

\section{Introduction}

The Indian squid (Uroteuthis (Photololigo) duvaucelii) is a commercially important and targeted species in trawl fishery operating in Arabian sea off Maharashtra. It is an Indo-Pacific species, distributed in Indian Ocean periphery, including the Arabian Sea and Red Sea, extending eastward from Mozambique to the South China Sea and Philippines Sea, occurring at depths between 30 and $170 \mathrm{~m}$, forming large aggregations during the spawning season (Silas et al., 1982). Two successive spawning congregations of Indian squid reported in 1990 and 1991 along the southern Karnataka coast (Mohamed, 1993). The population dynamics of $L$. duvauceli in Saurashtra waters was studied by Kasim (1985). An assessment of squid stocks off Madras and Cochin was made by Silas et al. (1986) and Meiyappan and 
Srinath (1989) have reported the growth and mortality rates of the Indian squid from Cochin. Although several authors reported population dynamics of Indian squid but at present minimal information available on geospatial distribution and unusual abundance of Indian squid off Maharashtra coast. As squid is short-lived species, it's abundance experiences annual variability and depends on environmental variability and recruitment success which complicates management. Pierce et al. (2008) stated cephalopods that respond to environmental variation both 'actively' (by migrating to areas with more favoured environmental conditions for feeding or spawning) and 'passively' with prevailing currents which results in variation in growth and survival according to conditions experienced. Preliminary experiments on application of participatory GIS in trawl fisheries of Karnataka and its prospects in marine fisheries resource conservation and management showed that the trawlers from Mangalore carried out trawling operations during 2007-10 from sea off Calicut in the south to off Ratnagiri in the north (Dineshbabu et al., 2012). Bhendekar et al. (2016) did resource mapping of trawl fisheries resources ob GIS platform. Singh et al. (2017) used Participatory GIS in the preparation of thematic maps of fisheries resources from trawlers, spatio-temporal distribution of trawl catch/bycatch and characterization of fishing activities of trawlers along the Ratnagiri coast, Maharashtra. The application of GIS to the marine domain, especially to fisheries, has been slow and limited, for a number of reasons (Wright, 1999; Meaden and Do Chi, 1996). Traditional assessment and management techniques have limited application in cephalopods fisheries management due to short-life-cycles (Pierce and Guerra, 1994). On the other hand, the sensitivity of cephalopod distribution and abundance to environmental variation in time and space (Coelho, 1985) makes them a particularly appropriate focus of studies based on GIS techniques. The collaboration between the fishing industry and research institutions provides good opportunities for data collection and subsequent analyses for a better understanding of spatial distribution of fishery resources.

During the present study spatio-temporal distribution of Indian squid were studied during April 2017 to May 2018 and unusual abundance of this species in trawl were observed during the month of October and November 2017.

\section{Material and methods}

\section{On board fishery data}

Squid fishery geospatial data during April 2017 to May 2018 were collected from multi-day trawlers operating from New Ferry Wharf, Sassoon Dock, Versova fish landing centre of Greater Mumbai district and Mirkarwada fish landing centre of Ratnagiri district of Maharashtra covering entire coastal stretch of the state (Fig. 1). In all, 168 hauling information

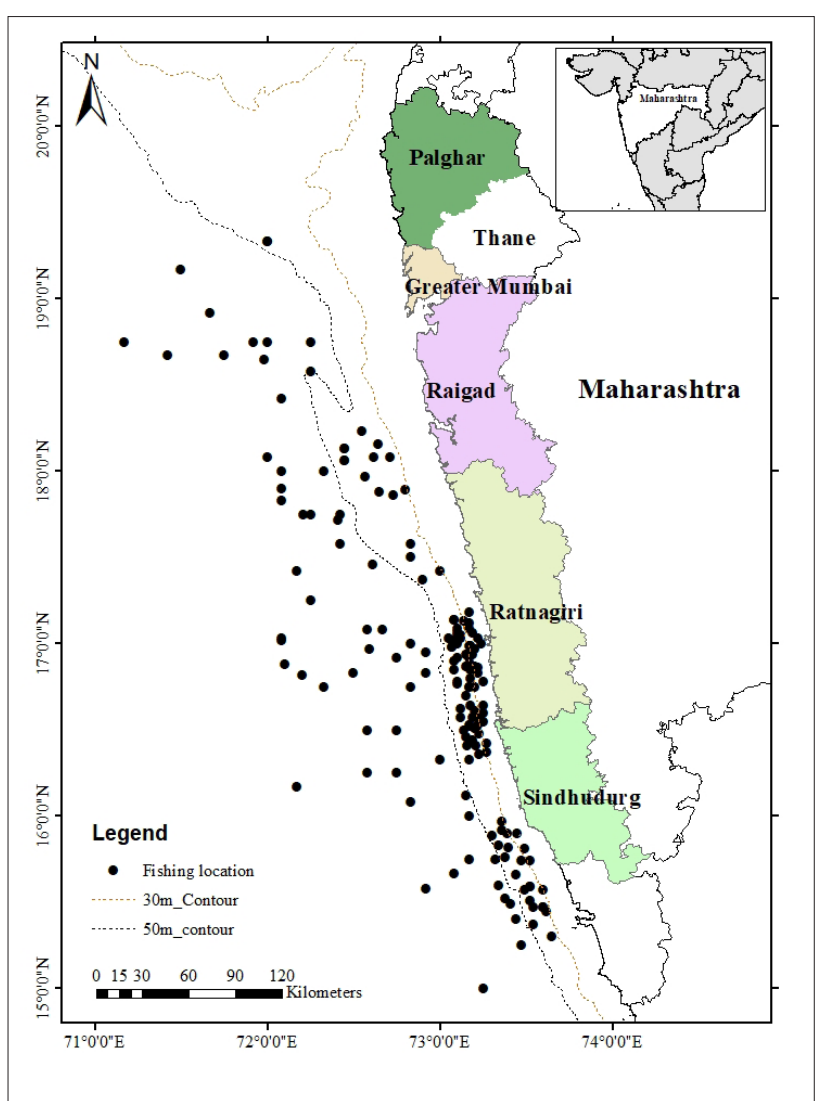

Fig. 1. Study area and spatial distribution of trawling fleet off Maharashtra coast

were collected during the study period. Information collected onboard consisted of date, depth of shooting and hauling of net, geolocation of fishing operation, time of shooting and hauling of net, mesh size (cod end), total catch ( $\mathrm{kg}$ ), total Indian squid catch $(\mathrm{kg})$ and number of hauls per day (Dineshbabu et al., 2012). Thus, month-wise data collected were used for spatial mapping of Indian squid. About $90 \%$ of the catch of Indian squid coming from trawlers (CMFRI, 2018) and fishers those have learned about the productive fishing grounds over a period of time. Along Maharashtra state, spatial extent of trawling activities are almost replica of resource distribution. The data collected were grouped into four pre-determined seasons; winter (December to February), pre-monsoon (March to May), monsoon (August to September) and post-monsoon (October -November) and distribution maps were prepared using inverse distance weighted (IDW) interpolation method in ArcGIS 10.2.

\section{Catch and effort data}

The Indian squid annual landing in Maharashtra from 2006 to 2018 recorded by the National Marine Living Resources Data Centre (NMLRDC) of ICAR-Central Marine Fisheries Research Institute (ICAR-CMFRI) were analysed and results are 
presented to show decadal and montly temporal fluctuation in catches. Monthly catch and efforts for trawl squid landing in 2017-18 were estimated by biweekly observations done at New Ferry Wharf, Sassoon Dock, Versova and Ratnagiri fish landing centres. The observed catch and effort were raised by the number of boats landed on the day to obtain the day's estimate, and all such figures were pooled and raised by the number of fishing days in the month to get the monthly catch and effort estimates (Mohamed, 1993). The decadal Indian squid fisheries data were analysed using Microsoft Excel 2016 and $R$ version 3.5.1.

\section{Environmental data}

To find out root cause for unusual landing during the months of October and November 2017 off Ratnagiri coast of Maharashtra, Sea Surface Temperature (SST) was retrieved from NASA Ocean Color web (https://oceancolor.gsfc.nasa.gov) for each day and month of $4 \mathrm{~km}$ spatial resolution. Sea surface height (SSH) and Salinity at $15 \mathrm{~m}$ depth were retrived from Copernicus Marine Environment (http://marine.copernicus.eu/services-portfolio/ access-to-products/) with 1/12 degree horizontal resolution and 50 vertical depth level and 1 day resolution. OSCAR (Ocean Surface Current Analysis Real-time) near-surface ocean current estimates, derived using quasi-linear and steady flow momentum equations (https://podaac.jpl.nasa.gov/dataset/OSCAR_L4_OC_ third-deg) on a $1 / 3$ degree grid with a 5 day resolution. The retrieved parameters were Sea Surface Temperature (SST) in ${ }^{\circ} \mathrm{C}$, Sea water salinity at $15 \mathrm{~m}$ depth (Sal_15m) parts per thousand, Sea Surface Height above geoid (SSH) in metre and ocean current speed (current) in $\mathrm{cm} / \mathrm{s}$. The point data extraction and image processing were done in SeaDAS 7.5.1. Correlation of these parameters with catch per unit efforts of trawl net were plotted in R version 3.5.1.

\section{Results}

\section{Decadal catch trend}

The squid landing in last decade shows wide fluctuation ranging from 8.22 thousand metric ton in 2006 to 27.86 thousand metric tonnes in 2017 (Fig. 2). Trawl was the major gear contributing $90-95 \%$ of total Indian squid landing followed by Dol (Bag) net and hook and line. In last decade, contribution of squid to total marine fish landing of Maharashtra rose from $2 \%$ to $7.3 \%$. The decadal landing shows two peaks in 2012 and 2017. Decadal catch analysis shows steep increase in catch of Indian squid from 2014 to 2017. Increase in the catch of Indian squid in recent past may be attributed to targeted fishery by high speed midwater trawling, changes in dimension of trawl net, increase in horse power of engine of fishing vessel and light fishing.

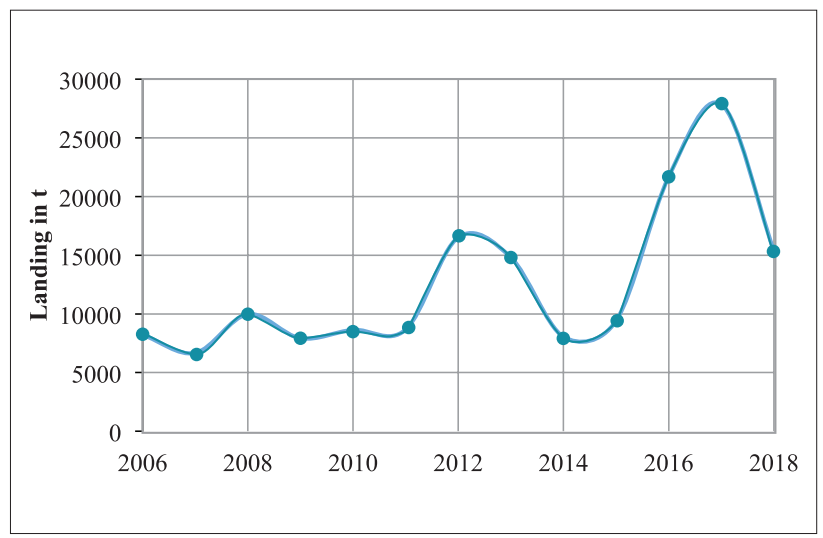

Fig. 2. Decadal variation in squid landing off Maharashtra coast

\section{Monthly variability and abundance}

The monthly catch and catch per hour of Indian squid from trawl net during 2017-18 showed peak landing just after monsoon ban during August to October month (Fig. 3). Indian squid landing during August to October confined to $15^{\circ} \mathrm{N}$ to $17^{\circ} \mathrm{N}$ latitude in 15 to $60 \mathrm{~m}$ depth off south Maharashtra. In summer, Indian squid landing shows second peak during March-April months.

Geospatial analysis of on-board fisheries data showed monthwise spatial changes in fishing grounds of Indian squid fisheries off Maharashtra. Spatial abundance based on catch per hour of trawlers indicated that most of the Indian squid landing was coming from South Maharashtra. As fishing season progresses after monsoon fishing ban (June-July) Indian squid fishing grounds move from south to north Maharashtra.

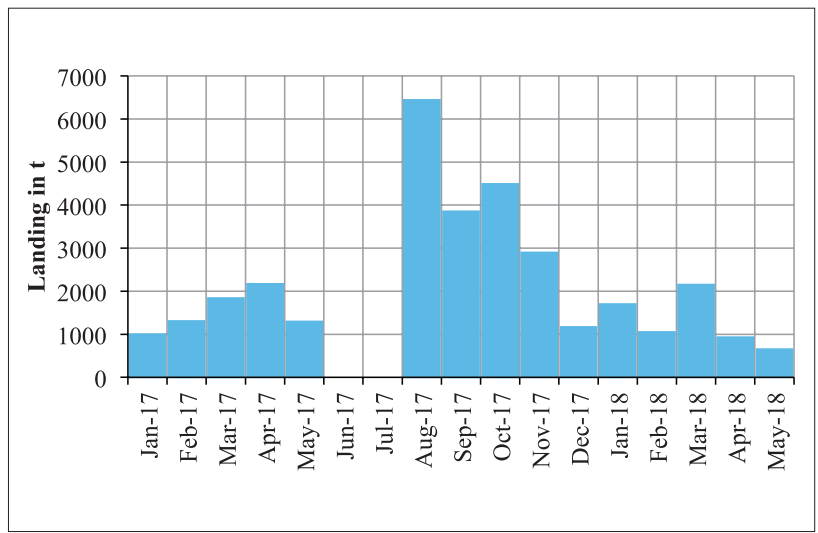

Fig. 3. Monthly landing (2017-18) of Indian squid in trawl net off Maharashtra coast, India

\section{Latitudinal variability}

The annual latitudinal variability in trawl fisheries for Indian squid revealed three different fishing patterns (Fig. 4). After fishing 

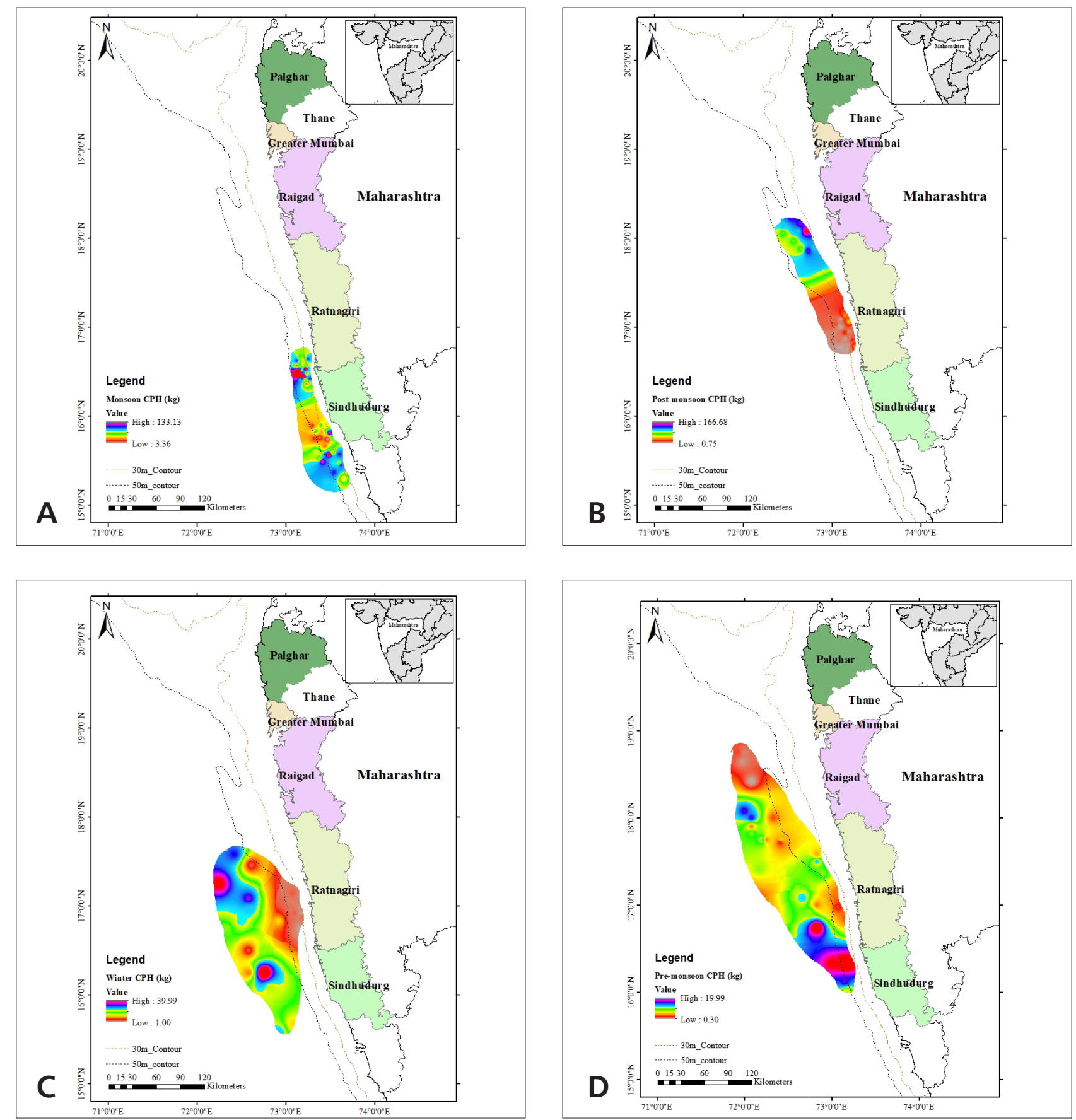

Fig. 4. Seasonal spatial distribution of Indian squid during A) monsoon, B) post- monsoon, C) winter, D) pre-monsoon (2017-18)

ban during June-July, in August fishers target Indian squid in $17^{0} \mathrm{~N}$ to $16^{0} \mathrm{~N}$ latitudinal range with fishing fleet concentrating in 20-40 m depth range catching on an average $55( \pm 36) \mathrm{kg}$ per hour of Indian squid per hour. In September, fishing fleet moved further down from $16^{0} \mathrm{~N}$ to $15^{\circ} \mathrm{N}$ in 40-60 m depth with average catch per hour of $43( \pm 23) \mathrm{kg} / \mathrm{hr}$. As season advances the trawl fishing fleet for Indian squid became more scattered moving towards north in the latitudinal range of $17^{\circ} \mathrm{N}$ to $20^{\circ} \mathrm{N}$ with reduced catch per hour. Annual bathymetric distribution of squid fishing fleet showed that most of the efforts were concentrated in 30 to $50 \mathrm{~m}$ depth.

\section{Unusual abundance}

During the month of mid-October to mid- November 2017 there was sudden spurt in Indian squid catch along Ratnagiri district 
off Maharashtra. Dorsal Mantle length (DML) of Indian squid ranges from 156 to $381 \mathrm{~mm}$. The length measurement (DML) of Indian squid shows that almost all the individuals were of above length at first maturity.

Pairplot (Fig. 5) for Sea Surface Temperature (SST_sur) in ${ }^{\circ} \mathrm{C}$, Sea water salinity at $15 \mathrm{~m}$ depth (Sal_15) parts per thousand, Sea Surface Height above geoid (SSH) in metre and ocean current speed (current) in $\mathrm{cm} / \mathrm{s}$ with catch per hour (CPH) as index of abundance showed strong positive correlation between $\mathrm{CPH}$ and SST (0.79). The nearly straight line between CPH and SST in this plot indicate a strong linear relationship. The number below the diagonal are (absolute) correlation coefficients. The font size of the cross-correlation is proportional to its strength.

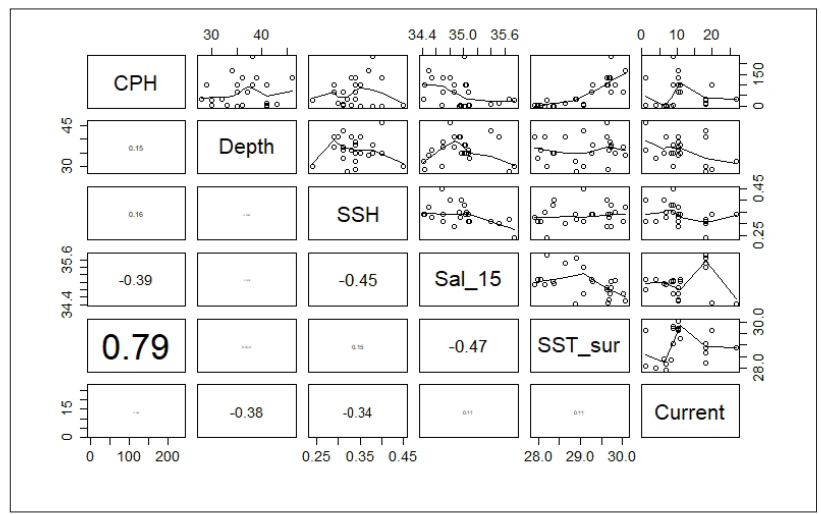

Fig. 5. Pair-plot of environment variables with catch per hour indicating correlation.

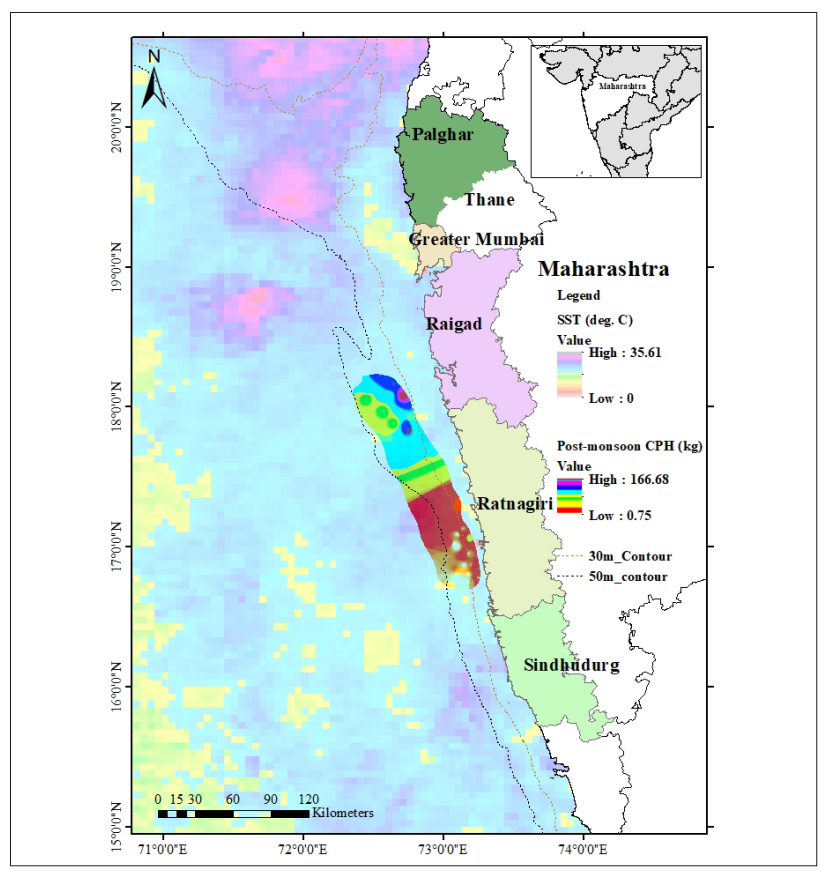

Fig. 6. Sea surface temperature and CPH during unusal abundance (OctNov 2017)
The lines in the upper diagonal panels are smoothers. The SST and $\mathrm{CPH}$ ovelay during unusal abundance showed in Fig. 6 .

\section{Discussion}

Average annual cephalopod production in India during 200110 was $1,27,937 \mathrm{t}$, contributing $3.41 \%$ to the world catch of cephalopods (Chakraborty et al., 2013). Stock assessment and biology of important cephalopod resources along the Indian coast have been studied by several researchers but information on fisheries is scanty (Thomas and Kizhakudan, 2006).

Till 1967, the cephalopod landings were low, though Maharashtra percentage contribution to the country's landings was quite high. From 1968 to 1975 the landings were moderately high, 147501 t (Silas et al., 1986). Along Maharashtra coast, maximum landings of cephalopods were in post-monsoon and pre-monsoon during 1984-88. Trawl net mostly contributed to cephalopod landing (Alagraja, 1992). In the present study decadal analysis also shows wide fluctuation in Indian squid landing and steep increase in recent past because of Maharashtra fishers started targeting Indian squid with specially designed trawl net and introduction of high horse power marine engine in trawlers. Monthly fluctuation in landing may be attributed to Indian squid seasonality and more fishers along Maharashtra coast target cephalopod resources at the time of abundance.

Scattered fishing positions of Jumbo flying squid (Dosidicus gigas) fishery in Peru could indicate where exactly fishing grounds were located. The spatial recurrence of fishing in the same area for a long period was evidence of resource availability (Paulino et al., 2016). Present study reveals targeted fishing grounds for Indian squid in different months. The annual latitudinal variability in trawl fisheries for Indian squid revealed three different fishing patterns. During August, fishers target Indian squid in $17^{\circ} \mathrm{N}$ to $16^{0} \mathrm{~N}$ latitude with fishing fleet concentrating in $20-40 \mathrm{~m}$ depth. In September, fishing fleet moved further down in $16^{\circ}$ $\mathrm{N}$ to $15^{\circ} \mathrm{N}$ in $40-60 \mathrm{~m}$ depth. As season advances the trawl fishing fleet for Indian squid became more scattered moving towards north in the latitudinal rage of $17^{\circ} \mathrm{N}$ to $20^{\circ} \mathrm{N}$.

The Indian squids were reported to form large congregations in inshore waters during the spawning season and at this time they are caught by purse seiners in Hong Kong using lights (Roper et al., 1984).

The occurrence of such sizeable quantities of large sized mature squids during September-October of 1990 and 1991 indicates that the squids might have congregated for spawning in the eastern Arabian Sea off southern Karnataka (Mohamed, 1993). The fact that they were caught by the purse seine, a gear meant 
principally for schooling species, lends credence to this view. Along the southwest coast of India, the surface and sub-surface seawater temperatures in the inshore areas evince a sudden increase during Sept.-Oct. after the southwest monsoon and this could probably explain the present congregation of squids (Mohamed, 1993). Present study confirms that the increased sea surface and sub surface temperatures are responsible for congregation and unusual abundance in the catches.

The monthly landing of Indian squid in trawl net during 2017-18 shows peak landing during August, September and October. The annual latitudinal variability in trawl fisheries for Indian squid revealed three different fishing patterns viz. August $\left(17^{\circ}\right.$ $\mathrm{N}$ to $16^{\circ} \mathrm{N}$ latitude), September ( $16^{\circ} \mathrm{N}$ to $15^{\circ} \mathrm{N}$ latitude) and scattered fishing positions in rest of months. Along the west coast of India, the surface and sub-surface seawater temperatures in the inshore areas evince a sudden increase during Oct-Nov. after the southwest monsoon and this could probably explain the present congregation of squids. The event must be occurring annually along the southwest coast of India with varying intensities depending on favourable environmental conditions.

\section{Acknowledgements}

We express our sincere gratitude to the Director, ICAR-Central Marine Fisheries Research Institute, Kochi for providing facilities for the work. We also thank the Director, ICAR-Central Institute of Fisheries Education, Mumbai for his kind support.

\section{References}

Alagaraja, K., K. Balan, K. S. Scariah, K. Vijayalakshmi, J. Andrews and C. J. Prasad. 1992. Marine fish production of maritime states of the west coast of India. Bull. Cent. Mar. Fish. Res. Inst., 45: 38 - 55.

Bhendekar, S. N., L. Shenoy, S. G. Raje, A. Chellappan and R. Singh. 2016. Participatory GIS in trawl fisheries along Mumbai coast, Maharashtra. Indian J. Mar. Sci., 45(8): 937-942.
Chakraborty, S. K., R. S. Biradar, A. K. Jaiswar, R. Palaniswamy and P. Kumar. 2013. Growth, mortality and population parameters of three cephalopod species, Loligo duvauceli (Orbigny), Sepia aculeata (Orbigny) and Sepiella inermis (Orbigny) from north-west coast of India. Indian J. Fish., 60(3) : 1-7.

CMFRI. 2018. Annual Report 2017-18. Central Marine Fisheries Research Institute, Kochi. 304 p.

Coelho, M. L. 1985. Review of the influence of oceanographic factors on cephalopod distribution and life cycles. NAFO Scientific Council Studies, 9: 47-57.

Dineshbabu, A. P. S. Thomas, E. V. Radhakrishnan and A. C. Dinesh. 2012. Preliminary experiments on application of participatory GIS in trawl fisheries of Karnataka and its prospects in marine fisheries resource conservation and management. Indian J. Fish 59 (1):15-22.

Kasim, H. M. 1985. Population dynamics of the squid Loligo divauceli Orbigny (Cephalopoda) in Saurashtra waters. J. Mar. Biol. Assoc. India, 27(1\&2): 103-112.

Meaden, G. J. and T. Do Chi. 1996. Geographical Information Systems: Application to Marine fisheries. Fisheries Tech. Pap. no. 356. Food and Agriculture Organization of the United Nations, Rome.

Meiyappan, M. M. and M. Srinath. 1989. Growth and mortality of the Indian squid (Loligo duvauceli) off Cochin, India. In S. C. Venema and N. P. VanZalinge, eds. Contributions to tropical fish stock assessment in India. FAO, Rome. 157pp.

Mohamed, K. S. 1993. Spawning congregations of Indian squid Loligo duvauceli (Cephalopoda : Loliginidae) in the Arabian Sea off Mangalore and Malpe. Indian J. Mar. Sci., 22: 172-175.

Paulino, C., M. Segura and G. Chacón. 2016. Spatial variability of jumbo flying squid (Dosidicus gigas) fishery related to remotely sensed SST and chlorophyll-a concentration (2004-2012). Fish. Res., 173: 122-127.

Pierce, G. J. and A. Guerra. 1994. Stock assessment methods used for cephalopod fisheries. Fish. Res., 21: 255-285.

Pierce, G. J., V. D. Vanivilas, A. Guerra, P. Jereb, L. Orsi-Relini, J. M. Bellido, I. Katara, U. Piatkowski, J. Pereira, E. Balguerias, I. Sobrino, E. Lefkaditou. J. Wang, M. Santurtun, P. R. Boyle, L. C. Hastie, C. D. MacLeod J. M. Smith, M. Viana, Gonza'lez and A. F. Zuur. 2008. A review of cephalopod-environment interactions in European Seas. Hydrobiologia, 612:49-70.

Roper, C. F. E., M. J. Sweeney and C. E. Nauen. 1984. FAO Fish Synap., 125:87.

Silas, E. G., M. M. Meiyappan, R. Sarvesan, K. P. Nair, M. Srinath and K. S. Rao. 1986. Stock assessment: Squids and cuttlefishes at selected centres. Bull. Cent. Mar. Fish. Res. Inst., 37: 71-79.

Silas, E. G., K. S. Rao, R. Sarvesan, K. P. Nair and M. M. Meiyappan. 1982. The exploited squid and cuttlefish resources of India. A review. In: Mar. Fish. Infor. Serv. In: T \& E Ser., 34:1-16.

Singh, J., R. Singh, A. Mohite, S. N. Bhendekar and L. Shenoy. 2017. Incorporating traditional knowledge with geographic information systems for management of marine resources along the Ratnagiri coast, Maharashtra. J. Env. Bio-Sci., 31 (1) : 27-31.

Thomas, S. and S. J. Kizhakudan. 2006. Cephalopod fishery and population dynamics of Loligo duvauceli (Orbigny) off Saurashtra region, Gujarat. Indian J. Fish., 53 (4): 425-430.

Wright, D. J. 1999. Down to the sea in ships: the emergency of marine GIS. In D. J. Wright and D.J. Bartlett (Eds.) Marine and Coastal Geographical Information System. Taylor \& Francis, 1-10 